Supporting Information

for

\title{
Role of Divalent Cations in Plasmid DNA Adsorption to Natural Organic Matter-Coated Silica Surface
}

\author{
Submitted to \\ Environmental Science \& Technology
}

2007

Thanh H. Nguyen ${ }^{* \dagger}$ and Kai Loon Chen

Department of Civil and Environmental Engineering, University of Illinois at UrbanaChampaign, 3230 Newmark Laboratory, Urbana, Illinois 61801 and Department of Chemical Engineering, Environmental Engineering Program, Yale University, New Haven, Connecticut 06520-8286

* To whom correspondence should be addressed. Phone: 217-244-5965. Fax: 217-3336968. Email: thn@uiuc.edu. ${ }^{\dagger}$ University of Illinois at Urbana-Champaign. ${ }^{\star}$ Yale University 
(a) linear plasmid adsorption in

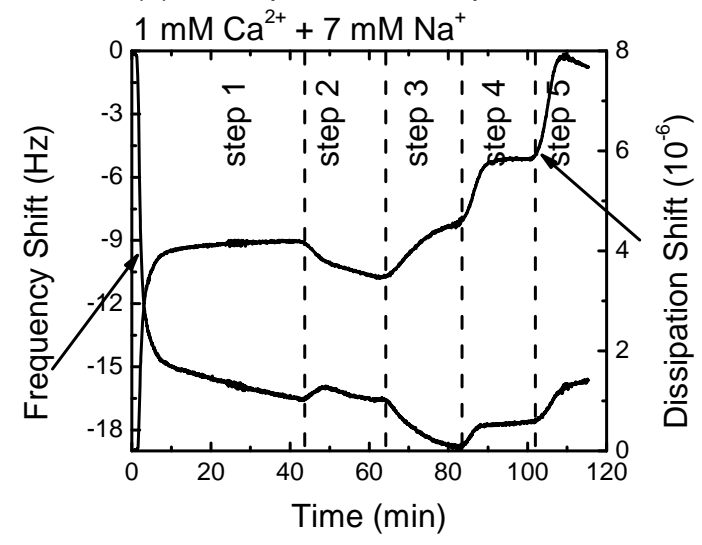

(b) linear plasmid adsorption in

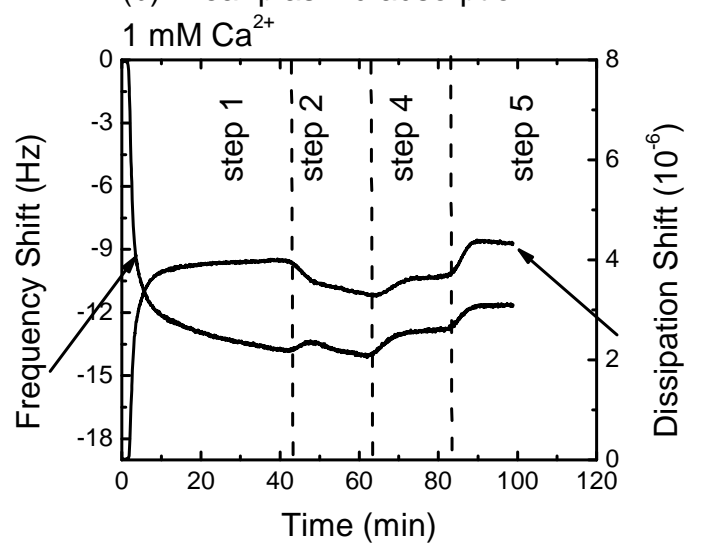

Figure 1S. Frequency shifts normalized by the third harmonic number and their associated dissipation shifts as a function of time for linear plasmid DNA adsorption at ambient $\mathrm{pH}$ of 5.8 and in the presence of $\mathrm{Ca}^{2+}$. The plasmid DNA concentration employed in the experiments was $120 \mathrm{mg} / \mathrm{L}$ and temperature was maintained at $25{ }^{\circ} \mathrm{C}$. (a) The plasmid DNA adsorption took place in $1 \mathrm{mM} \mathrm{CaCl}_{2}$ and $7 \mathrm{mM} \mathrm{NaCl}$ (step 1). The adsorbed plasmid DNA layer was washed with $1 \mathrm{mM} \mathrm{CaCl}_{2}$ and $7 \mathrm{mM} \mathrm{NaCl}$ solution (step 2), $10 \mathrm{mM} \mathrm{NaCl}$ solution (step 3), $1 \mathrm{mM} \mathrm{NaCl}$ solution (step 4), and DI water (step 5). (b) The plasmid DNA adsorption took place in $1 \mathrm{mM} \mathrm{CaCl}_{2}$ (step 1). The adsorbed plasmid DNA layer was washed with $1 \mathrm{mM} \mathrm{CaCl}_{2}$ solution (step 2), $1 \mathrm{mM}$ $\mathrm{NaCl}$ solution (step 4), and DI water (step 5). 
(a) linear plasmid adsorption in

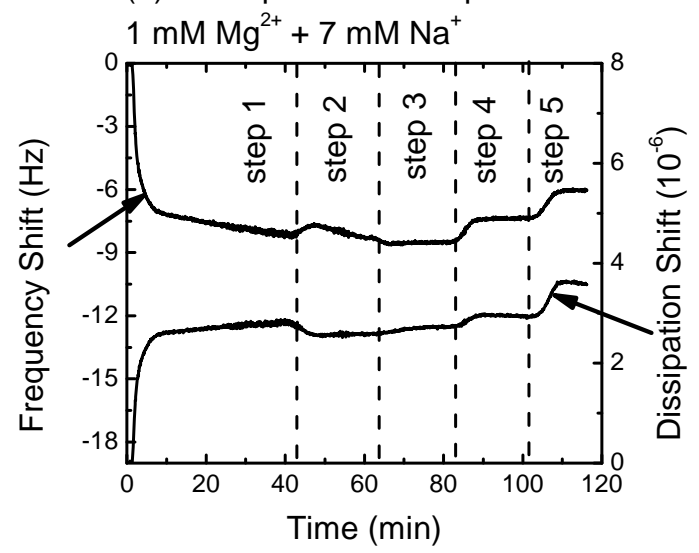

(b) linear plasmid adsorption in

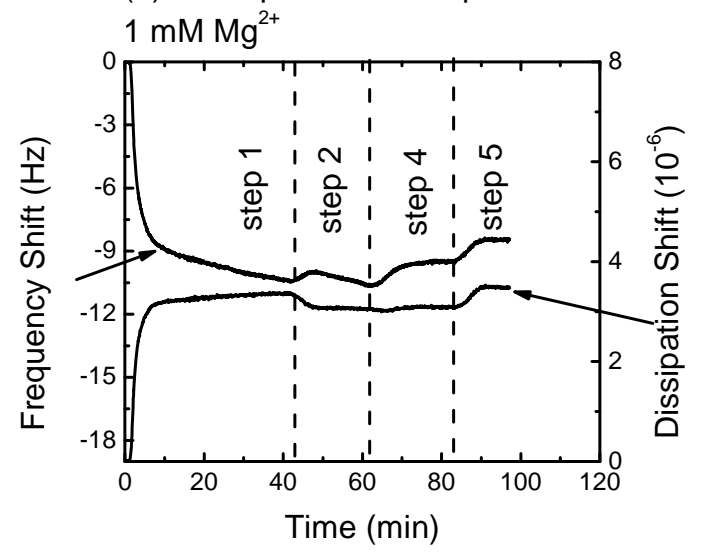

Figure 2S. Frequency shifts normalized by the third harmonic number and their associated dissipation shifts as a function of time for linear plasmid DNA adsorption at ambient $\mathrm{pH}$ of 5.8 and in the presence of $\mathrm{Mg}^{2+}$. The plasmid DNA concentration employed in the experiments was $120 \mathrm{mg} / \mathrm{L}$ and temperature was maintained at $25^{\circ} \mathrm{C}$. (a) The plasmid DNA adsorption took place in $1 \mathrm{mM} \mathrm{MgCl}_{2}$ and $7 \mathrm{mM} \mathrm{NaCl}$ (step 1). The adsorbed plasmid DNA layer was washed with $1 \mathrm{mM} \mathrm{MgCl}_{2}$ and $7 \mathrm{mM} \mathrm{NaCl}$ solution (step 2), $10 \mathrm{mM} \mathrm{NaCl}$ solution (step 3), $1 \mathrm{mM} \mathrm{NaCl}$ solution (step 4), and DI water (step 5). (b) The plasmid DNA adsorption took place in $1 \mathrm{mM} \mathrm{MgCl}_{2}$ (step 1). The adsorbed plasmid DNA layer was washed with $1 \mathrm{mM} \mathrm{MgCl}_{2}$ solution (step 2), $1 \mathrm{mM} \mathrm{NaCl}$ solution (step 4), and DI water (step 5). 

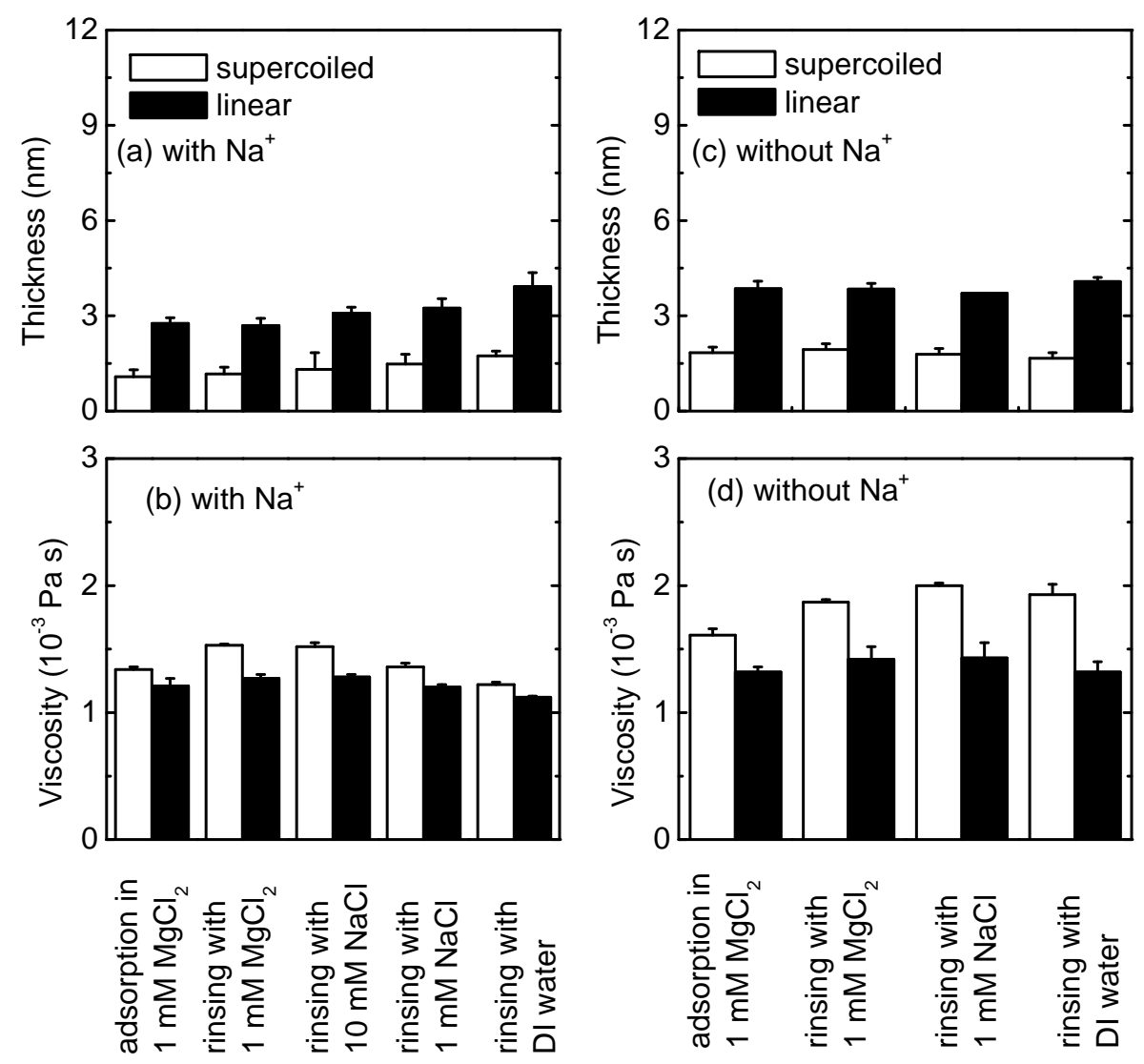

Figure 3S. Plots of estimated thicknesses (a) and shear viscosities (b) of the adsorbed plasmid DNA layers in different ionic compositions at ambient $\mathrm{pH}$. The plasmid DNA adsorption took place in $1 \mathrm{mM} \mathrm{MgCl} 2$ with and without background $\mathrm{Na}^{+}$. Shown are representative data for at least 2 replicate measurements. Plasmid DNA concentration was $120 \mathrm{mg} / \mathrm{L}$ and temperature was $25^{\circ} \mathrm{C}$. 
NOM Solution Preparation. Suwannee River natural organic matter (NOM) was obtained from the International Humic Substances Society (IHSS, St. Paul, MN). The NOM solution was made by dissolving $54 \mathrm{mg}$ of the Suwannee River NOM in $100 \mathrm{~mL}$ of deionized (DI) water, after which it was stirred overnight and filtered through a sterile $0.22 \mu \mathrm{m}$ cellulose acetate filter. $20 \mathrm{~mL}$ of the NOM filtrate was mixed with $18 \mathrm{~mL}$ of $100 \mathrm{mM} \mathrm{NaCl}$ solution and $162 \mathrm{~mL}$ of DI water to make the final NOM solution in 10 $\mathrm{mM} \mathrm{NaCl}$. This NOM solution was filtered again and stored in the dark at $4{ }^{\circ} \mathrm{C}$ until use. The total organic carbon (TOC) content of the filtered NOM solution was $21.83 \pm 0.13$ $\mathrm{mg} / \mathrm{L}$ (duplicate measurements of 21.92 and $21.74 \mathrm{mg} / \mathrm{L}$ ).

Salt solution preparation. The electrolyte $\left(\mathrm{NaCl}, \mathrm{CaCl}_{2}\right.$, and $\left.\mathrm{MgCl}_{2}\right)$ stock solutions were prepared by dissolving the salts (Fisher Scientific, ACS reagent grade) in DI water. They were then filtered with $0.22 \mu \mathrm{m}$ cellulose acetate membrane filters (Whatman) and stored at $4{ }^{\circ} \mathrm{C}$ until use. For all experiments, the solution $\mathrm{pH}$ was maintained at 5.8. 
Table 1S. Best fittings for shear viscosity and effective thickness as obtained using the Voigt-based model

\begin{tabular}{|c|c|c|c|c|c|}
\hline Ionic Composition & $\begin{array}{l}\text { Viscosity } \\
\left(10^{-3} \text { Pa s) }\right.\end{array}$ & $\begin{array}{c}\text { Effective } \\
\text { Thickness (nm) }\end{array}$ & Ionic Composition & $\begin{array}{l}\text { Viscosity } \\
\left(10^{-3} \text { Pa s) }\right.\end{array}$ & $\begin{array}{c}\text { Effective } \\
\text { Thickness (nm }\end{array}$ \\
\hline \multicolumn{3}{|c|}{ Supercoiled DNA } & \multicolumn{3}{|c|}{ Linear DNA } \\
\hline $\begin{array}{l}\text { Adsorption in } 1 \mathrm{mM} \mathrm{CaCl}_{2} \\
\text { and } 7 \mathrm{mM} \mathrm{NaCl}\end{array}$ & $1.54 \pm 0.00$ & $4.33 \pm 0.30$ & $\begin{array}{c}\text { Adsorption in } 1 \mathrm{mM} \mathrm{CaCl}_{2} \text { and } 7 \\
\mathrm{mM} \mathrm{NaCl}\end{array}$ & $1.41 \pm 0.06$ & $5.54 \pm 0.11$ \\
\hline $\begin{array}{l}\text { Rinsing with } 1 \mathrm{mM} \mathrm{CaCl}_{2} \text { and } \\
7 \mathrm{mM} \mathrm{NaCl}\end{array}$ & $1.63 \pm 0.01$ & $4.29 \pm 0.25$ & $\begin{array}{l}\text { Rinsing with } 1 \mathrm{mM} \mathrm{CaCl}_{2} \text { and } 7 \\
\mathrm{mM} \mathrm{NaCl}\end{array}$ & $1.53 \pm 0.05$ & $4.99 \pm 0.03$ \\
\hline Rinsing with $10 \mathrm{mM} \mathrm{NaCl}$ & $1.61 \pm 0.03$ & $4.34 \pm 0.21$ & Rinsing with $10 \mathrm{mM} \mathrm{NaCl}$ & $1.53 \pm 0.02$ & $5.27 \pm 0.44$ \\
\hline Rinsing with $1 \mathrm{mM} \mathrm{NaCl}$ & $1.44 \pm 0.05$ & $4.83 \pm 0.41$ & Rinsing with $1 \mathrm{mM} \mathrm{NaCl}$ & $1.36 \pm 0.01$ & $6.53 \pm 0.72$ \\
\hline Rinsing with DI water & $1.35 \pm 0.12$ & $5.59 \pm 1.23$ & Rinsing with DI water & $1.21 \pm 0.01$ & $9.62 \pm 1.34$ \\
\hline Adsorption in $1 \mathrm{mM} \mathrm{CaCl}_{2}$ & $1.90 \pm 0.05$ & $3.02 \pm 0.36$ & Adsorption in $1 \mathrm{mM} \mathrm{CaCl}_{2}$ & $1.41 \pm 0.00$ & $3.95 \pm 0.81$ \\
\hline Rinsing with $1 \mathrm{mM} \mathrm{CaCl}_{2}$ & $2.12 \pm 0.03$ & $3.01 \pm 0.21$ & Rinsing with $1 \mathrm{mM} \mathrm{CaCl}_{2}$ & $1.60 \pm 0.14$ & $3.71 \pm 1.03$ \\
\hline Rinsing with $1 \mathrm{mM} \mathrm{NaCl}$ & $2.20 \pm 0.05$ & $2.90 \pm 0.25$ & Rinsing with $1 \mathrm{mM} \mathrm{NaCl}$ & $1.54 \pm 0.09$ & $3.82 \pm 0.87$ \\
\hline Rinsing with DI water & $2.02 \pm 0.05$ & $2.89 \pm 0.22$ & Rinsing with DI water & $1.38 \pm 0.10$ & $4.60 \pm 1.50$ \\
\hline $\begin{array}{l}\text { Adsorption in } 1 \mathrm{mM} \mathrm{MgCl} \\
\text { and } 7 \mathrm{mM} \mathrm{NaCl}\end{array}$ & $1.34 \pm 0.02$ & $1.08 \pm 0.22$ & $\begin{array}{c}\text { Adsorption in } 1 \mathrm{mM} \mathrm{MgCl}_{2} \text { and } \\
\qquad 7 \mathrm{mM} \mathrm{NaCl}\end{array}$ & $1.21 \pm 0.06$ & $2.76 \pm 0.18$ \\
\hline $\begin{array}{l}\text { Rinsing with } 1 \mathrm{mM} \mathrm{MgCl} \\
\text { and } 7 \mathrm{mM} \mathrm{NaCl}\end{array}$ & $1.53 \pm 0.01$ & $1.17 \pm 0.21$ & $\begin{array}{l}\text { Rinsing with } 1 \mathrm{mM} \mathrm{MgCl}_{2} \text { and } 7 \\
\mathrm{mM} \mathrm{NaCl}\end{array}$ & $1.27 \pm 0.03$ & $2.69 \pm 0.23$ \\
\hline Rinsing with $10 \mathrm{mM} \mathrm{NaCl}$ & $1.52 \pm 0.03$ & $1.31 \pm 0.53$ & Rinsing with $10 \mathrm{mM} \mathrm{NaCl}$ & $1.28 \pm 0.02$ & $3.08 \pm 0.19$ \\
\hline Rinsing with $1 \mathrm{mM} \mathrm{NaCl}$ & $1.36 \pm 0.03$ & $1.48 \pm 0.31$ & Rinsing with $1 \mathrm{mM} \mathrm{NaCl}$ & $1.20 \pm 0.02$ & $3.24 \pm 0.30$ \\
\hline Rinsing with DI water & $1.22 \pm 0.02$ & $1.74 \pm 0.15$ & Rinsing with DI water & $1.12 \pm 0.01$ & $3.92 \pm 0.44$ \\
\hline Adsorption in $1 \mathrm{mM} \mathrm{MgCl} 2$ & $1.61 \pm 0.05$ & $1.84 \pm 0.17$ & Adsorption in $1 \mathrm{mM} \mathrm{MgCl}{ }_{2}$ & $1.32 \pm 0.04$ & $3.85 \pm 0.24$ \\
\hline Rinsing with $1 \mathrm{mM} \mathrm{MgCl}{ }_{2}$ & $1.87 \pm 0.02$ & $1.94 \pm 0.18$ & Rinsing with $1 \mathrm{mM} \mathrm{MgCl}{ }_{2}$ & $1.42 \pm 0.10$ & $3.84 \pm 0.18$ \\
\hline Rinsing with $1 \mathrm{mM} \mathrm{NaCl}$ & $2.00 \pm 0.02$ & $1.79 \pm 0.18$ & Rinsing with $1 \mathrm{mM} \mathrm{NaCl}$ & $1.43 \pm 0.12$ & $3.71 \pm 0.00$ \\
\hline Rinsing with DI water & $1.93 \pm 0.08$ & $1.66 \pm 0.18$ & Rinsing with DI water & $1.32 \pm 0.08$ & $4.08 \pm 0.13$ \\
\hline
\end{tabular}

